\title{
IMAGENS PEDAGÓGICAS: LAMPEJOS PARA/DE UM MANIFESTO
}

IMÁGENES PEDAGÓGICAS: PARPADEOS HACIA / DESDE UN MANIFIESTO

https://orcid.org/0000-0003-0165-1430 Robson Guedes da Silva ${ }^{\text {A }}$

${ }^{\text {A }}$ Universidade Federal de Pernambuco (UFPE), Recife, PE, Brasil

Recebido em: 30 set. 2020 | Aceito em: 07 abr. 2021 Correspondência: Robson Silva (robsonguedes00@hotmail.com)

\begin{abstract}
Resumo
Este ensaio poético se lança a tecer possibilidades de manifestações, vendo o corpo como um texto-instrumento de reivindicação. Nutrido de um repertório pós-estruturalista, busca debater os enlaces corpo-gênero, entrevendo que as poéticas que são constituídas como embates na disputa pelo direito de aparecer e habitar o presente podem ser concebidas como imagens pedagógicas. O texto noticia que performances dissidentes e contrassexuais poderão ser engendradas através dessas visualidades, nas quais tessituras anárquicas despontam como possibilidades de reivindicação político-corporal.
\end{abstract}

Palavras-Chaves: Corpo; Performance; Subjetivação.

\section{Resumen}

Este ensayo poético se lanza a tejer posibilidades de manifestaciones, viendo el cuerpo como un texto-instrumento de reivindicación. Alimentado por un repertorio postestructuralista, busca debatir los vínculos cuerpo-género, señalando que las poéticas que se constituyen como choques en la disputa por el derecho a aparecer y habitar el presente pueden ser concebidas como imágenes pedagógicas. El texto señala que las actuaciones disidentes y contra-sexuales pueden ser engendradas a través de estas visualizaciones, en las que las tesituras anárquicas emergen como posibilidades de reivindicación político-corporal.

Palabras clave: Cuerpo; La actuación; Subjetivación.

Um levante, um traço, um risco. Manifestar! Erguer-se em enunciação contra certas clivagens do corpo e outros atravessamentos que se sucedem nele e a partir dele. Gritos, olhares, toques, corporalidades, aglutinado polimorfo de possibilidades políticas. $\mathrm{O}$ anúncio desconcertante era o de evidenciarmos a potência de nossa epiderme.

Cientes do nosso anunciar, seguimos em altivez. Nosso texto era composto de uma arquitetura que reivindicava novas posições de enunciação. Um embate com a linguagem, um efeito poluidor era nossa pretensão. Tal gesto carecia da percepção da força políticaperformativa que podemos mobilizar, um movimento que atenta contra qualquer enquadramento totalizador. 
Figura 1 - Homem de saia.

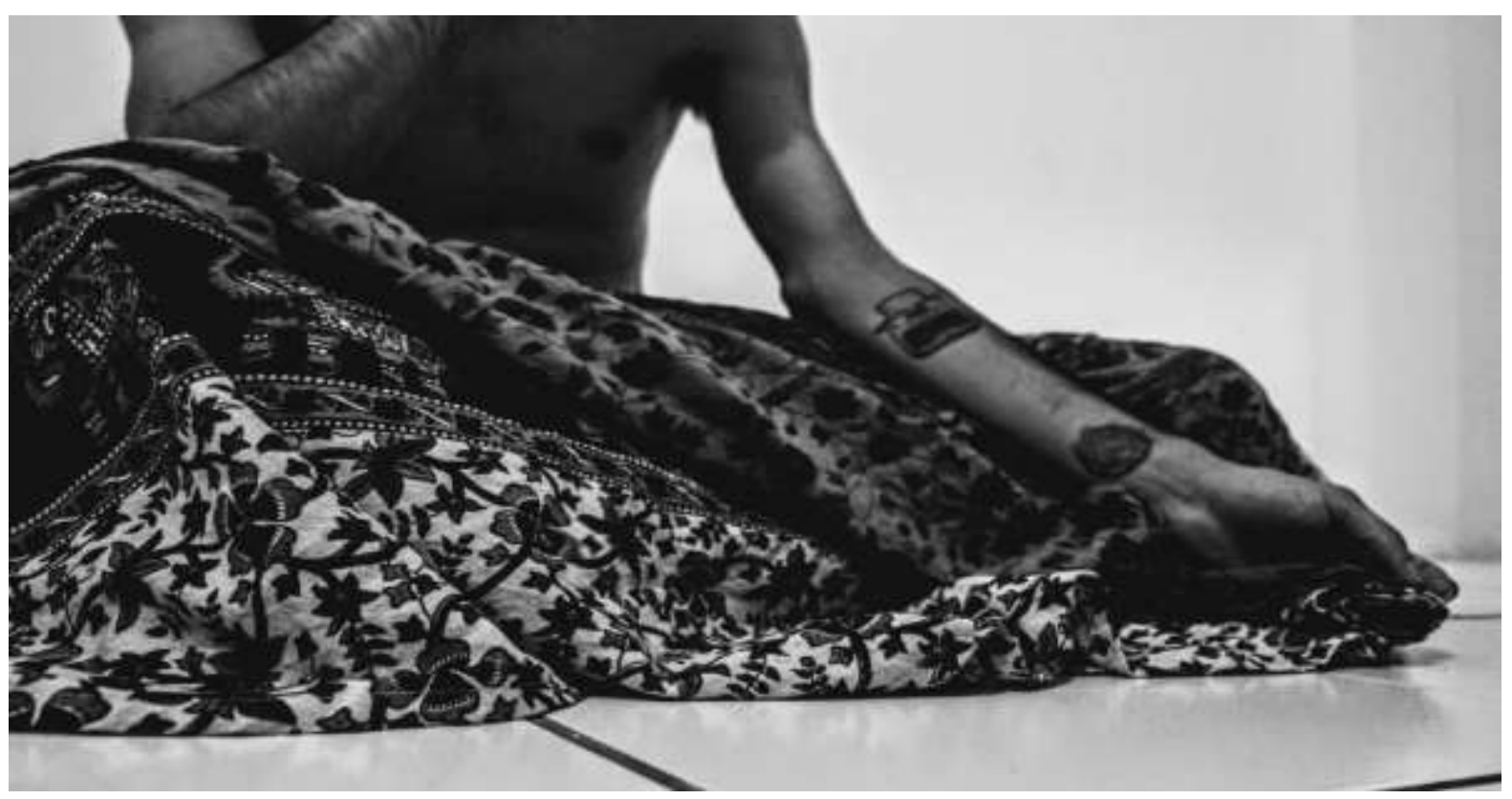

Foto: Thiago Antunes, 2017. 764 x 510, Recife-PE.

O intuito noticiado é o de debatermos, nutridos de um repertório pós-estruturalista, os enlaces que constituem os discursos sobre corpo e gênero, entrevendo as implicações de uma imagem pedagógica, uma visualidade que manifesta resistência contra toda uma inteligibilidade. Facultando neste gesto potente uma moda-militância, prática políticoperformativa que reivindica algo mais radicalmente comprometido: um presente longe de capturas normativas, que se apresenta por hora, em notas de manifestação.

O toque do método neste texto é embebido de uma filosofia queer, da composição de uma caixa de ferramentas teórico-metodológica que tece um repertório crítico, contribuindo para a escritura de um manifestar, tanto fruto de inquietações teóricas quanto de um apelo corporal à mobilização. Tensionando as relações corpo-gênero e provocando - neste gesto uma reflexão sobre as possibilidades que nosso corpo pode articular, é que este ensaio situa seu caminhar e olhar analítico.

Longe da pretensão apocalíptica de destruir as ruínas de um corpo moderno, denotamos apenas, os escombros da modernidade, o fantasma de seu 'Deus' defunto e o seu homem que já padece as prenúncias fúnebres de sua perdição. Nossos corpos, xerocados, hipotecados, conectados, compartilhados, encerrados, rompidos, danificados, interditados, estimulados, governamentalizados, agenciados, ousados, limitados, sensíveis, possíveis; estão em disputas discursivas, são lócus tanto de reiteração normativa quanto de fissura e desconstrução. 
Sem Éden, nem céu, o cotidiano infernal nos é posto em questão, panos, cortes, costuras, podem ser as possíveis armas dessa revolução estético-semiótica em que o corpo floresce como território de disputas. Longe de um dado passível no qual o biopoder atua, é igualmente potência mesma de sua reivindicação. É no encontro, no vinco entre o inesperado e a diferença, que tecemos o texto que se exala político, tensiona estatutos e advoga a contingência.

É pela força performativa do encontro que aqui defendemos queerificar e sacudir qualquer estatuto para/sobre os corpos, articulando novas formas de pensar quem estamos sendo e o que vamos fazer com o que fizeram de nós. É na farra, entre vinhos, gargalhadas, resistindo por meio de práticas subversivas de aparecimento, performances decididamente dissidentes, ataques político-estéticos a um estatuto natural para a visualidade de gênero, atentados que se insurgem contra uma arte de governar nossos corpos. Buscamos dinamitar um gênero que desde o século XXI

\begin{abstract}
funciona como um mecanismo abstrato para a subjetivação técnica; ele é conectado, cortado, deslocado, citado, imitado, engolido, injetado, transplantado, digitalizado, copiado, concebido como design, comprado, vendido, modificado, hipotecado, transferido, baixado na internet, aplicado, traduzido, falsificado, fabricado, trocado, dosado, administrado, extraído, contraido, ocultado, negado, renunciado, traído... Ele transmuta (PRECIADO, 2018, p. 139).
\end{abstract}

Notas são constituídas, poderão ser elas a corpora, a caixa de ferramentas, uma de tantas outras estratégias de luta, que funciona na emergência de pensar acerca das formas de resistência que se apresentam como possibilidades discursivas que, tomando as técnicas das mãos do poder, pirateando e tecendo novas engrenagens, - em contrapartida as que já se encontram colapsadas - articulam novas inteligibilidades. É no texto, na escrita cortante, - na terra dos renegados que se almejam salvos, que devaneiam o Éden e produzem enxofre - que os corpos são convidados à revolta.

Nesta disputa discursiva, ecoar notas, movimentos, rodopios e saberes difusos são importantes instrumentos para tecer um enunciado, para mobilizar efeitos, para inventar o arquivo. Corpos tomando as rédeas da subjetivação, um devir-corpo, corpo-texto. Não é uma promessa, é enlace, uma contraconduta que rearticula outras formas de visibilidade e dizibilidade.

O gesto que se apresenta é de pensarmos as implicações das relações de poder do sistema sexo-gênero, refletindo acerca de como as compreensões de gênero e sexo são fíctícias e fabricadas, instadas à superfície corporal mediante relações sociais desiguais que facultam a naturalização da normalização (LOURO, 1997). 
Nós, convidamos, intimamos, provocamos. Longe de ensejar o fim do mundo, de sermos mais uma estatística de uma guerra, em que nossos corpos só morrem para que outros corpos permaneçam instados à norma. Queremos amalgamar palavras proibidas, conjurar feitiços profanos que pecam por denunciar os limites do natural. Manifestações: uma assembleia, uma coletividade que não advoga a diversidade em detrimento da diferença. Corpos que articulam movimentos outros, que agem politicamente para serem compreendidos como apenas corpos falantes, para que as tessituras corporais discursivas não operem da maneira como estão programadas neste espaço tecno-orgânico, nem tampouco capturadas pelo gênero, haja vista que

o gênero é um programa operacional capaz de desencadear uma proliferação de percepções sensoriais sob a forma de afetos, desejos, ações, crenças e identidades. Um dos resultados característicos desta tecnologia de gênero é a produção de um saber interior sobre si mesmo, de um sentindo de um eu sexual que aparece como uma realidade emocional para a consciência (PRECIADO, 2018, p. 127).

Nossos inimigos tecem discursos que buscam sempre salientar nosso estar no mundo a uma imutável exatidão, na qual a identidade é corporificada, circunscrevendo os mimetismos da normalização. Nossas pautas: sempre em construção. Nossa inquietação: como articularmos, sem exterioridade à norma, formas de vida que tensionam um regime da aparência e politizam o estar no mundo para além de um estatuto do reconhecimento? Estes rascunhos, infames, blasfemadores, abraçam a força performativa que nossos corpos constituem e se lançam a provocar, devanear formas de estar no presente, formas de resistência contra todo um processo que limita a potência do que podemos produzir em torno de nós mesmos.

\section{II}

Acusam-nos nesta inquisição contemporânea, de tentarmos destruir a intocável e inalienável natureza, enquanto apenas apresentamos os efeitos de verdade da naturalização, sua produção, seus limites e suas contradições. Estranhos, invertidos, imundos. Gritam que somos os abjetos dignos da fogueira que normatiza. Se com fogo querem nos enquadrar, é pelo fogo que devemos resistir!

Incendiar as ruas com as nossas presenças em chamas, nos consumindo em narrativa, uma contra-produção que rearranja afetações, compreensões, que incita deslocamentos. Saberes que emergem da imagem que constituímos, nosso convite é antes de tudo, viabilizarmos formas de estar nas ruas, tecendo sempre um texto em movimento, uma imagem pedagógica que reverbera efeitos múltiplos. 
Figura 2 - Homem de saia.

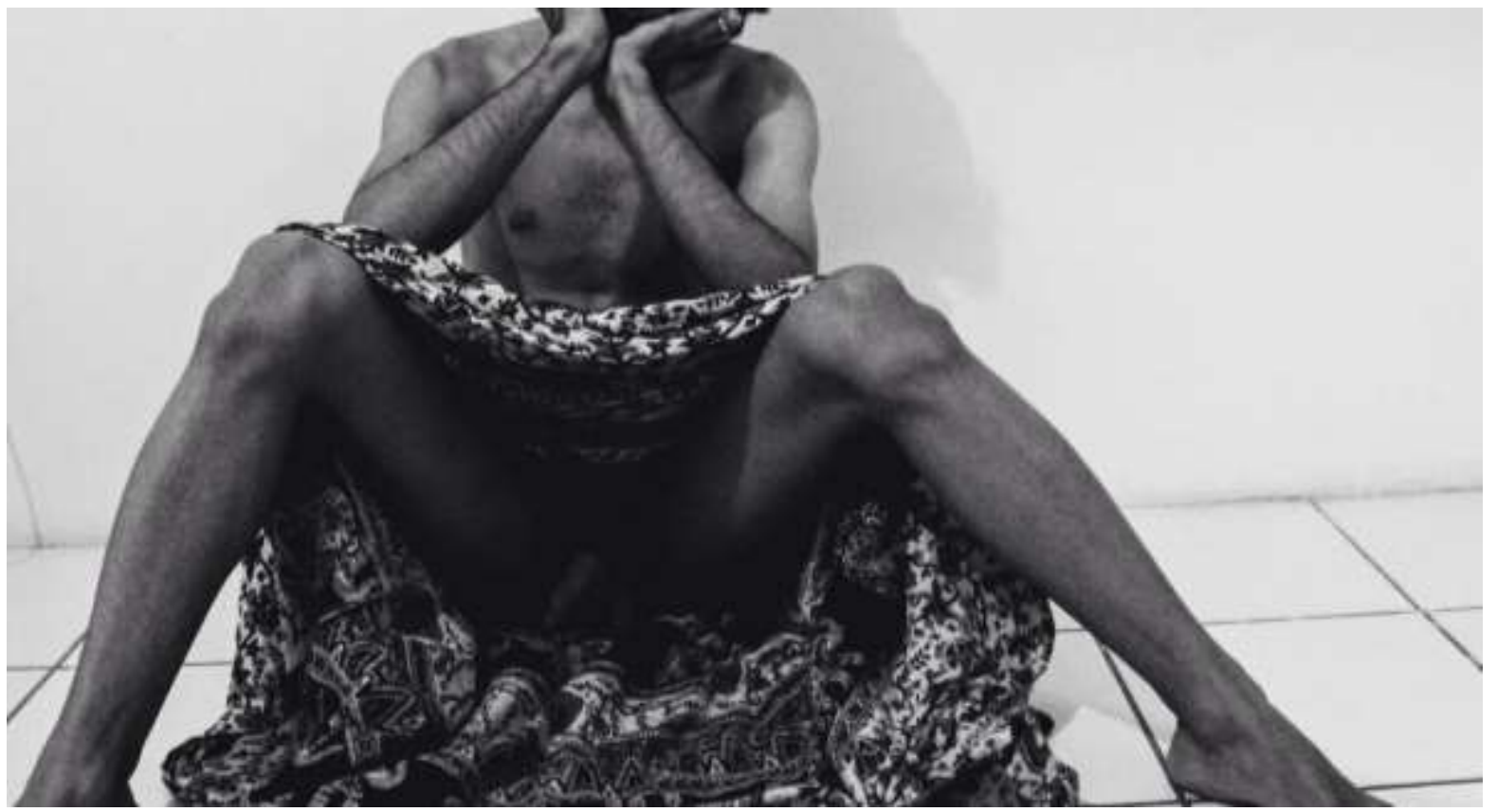

Foto: Thiago Antunes, 2017. 756 x 520, Recife-PE.

Pensamos, neste sentindo, a imagem pedagógica como o efeito de uma prática queer, como algo que advoga a contingência, a imagem pedagógica se apresenta como uma política performativa que evidencia mesmo sem exterioridade a norma, o trânsito que os corpos na história constituem, denunciando que categorias como feminino e masculino são fabricados e fictícios.

A imagem como um regime discursivo, longe de ser pensada como apenas um enquadramento que captura e representa um enunciado real. É movimento. Sempre se apresenta em provisoriedade, evidencia e mobiliza outras possibilidades de pensar acerca de nossos corpos. Outras oportunidades de reflexão em torno de nossa subjetividade, de como nos constituímos e quais as perspectivas de desconstrução se despontam nesse processo.

O corpo assume com/pela imagem pedagógica, o trânsito como contínua prática de estar no mundo, um efeito poluidor que confunde as certezas naturalizadas de gênero, sexualidade, verdade, etc. Um espelho no qual se observa um devir-corpo, um signo que denuncia em sua tessitura discursiva a visualidade de gênero como representação mimetizada da heterossexualidade compulsória.

$\mathrm{Na}$ força produtiva dos encontros, malogrando e apresentando fissuras no processo de reiteração da norma, alguns corpos compõem certo movimento performativo, desafiando a continuidade da fabricação normativa em suas produções de corpos instados a uma 
padronização. Formas de vida que em um campo determinado de forças abraçam um movimento aberrante, lançam-se em uma dança cotidiana que advoga por meio da performance outras possibilidades de uma vida vivivel. Butler aponta que

verifica-se que não pode haver reprodução das normas generificadas sem a representação corporal dessas normas, e quando esse campo de normas se rompe, mesmo que provisoriamente, vemos que os objetivos estimuladores de um discurso regulatório, como ele é representado corporalmente, têm consequências nem sempre previstas, abrindo caminhos para formas de viver o gênero que desafiam as normas de reconhecimento predominantes (BUTLER, 2018, p. 39).

A imagem pedagógica pode funcionar como um artefato de subjetivação, um entre, em que uma gama de possibilidades educativas são produzidas e reinventadas, um território discursivo no qual certa pirataria contrassexual estabelece saberes difusos nunca instados a uma única significação. Movimentos que são práticas educativas por que mobilizam outras formas de pensar as subjetividades, possibilidades outras de constituição dos sujeitos, assim como novas formas de conceber os corpos em seu devir. Rompendo com uma visão positivista dos processos de produção de saberes, a imagem pedagógica, não se lança a fixar um estatuto de visualidade-representação dos corpos, almeja a contingência, com uma imagem que assume como vocação a permanente prática de incitar problemas, de questionar concepções naturalizadas e de irrefutável verdade.

Entendendo que o corpo não existe pré-discursivamente, podemos neste sentido, como nos afirma Preciado, concebê-lo como

[...] um texto socialmente construído, um arquivo orgânico da história da humanidade como história da produção-reprodução sexual, na qual certos códigos se naturalizam, outros ficam elípticos e outros são sistematicamente eliminados ou riscados (PRECIADO, 2014, p. 26).

Este corpo - no qual "estamos dolorosamente conscientes do que significa ter um corpo historicamente constituído. Mas com a perda da inocência sobre nossa origem, tampouco existe qualquer expulsão do Jardim do Éden” (HARAWAY, 2009, p. 51), - é superfície, terreno precário, corpo-plástico.

Nosso querer não se encerra apenas em tensionar as escrituras de sexo e de gênero exaurindo a binaridade como única possibilidade de significação. É através de uma prática contrassexual, atendo-se aqui ao Preciado (2014), por meio da derrubada dos lugares de enunciação e dos privilégios que tais produzem, pirateando outras narrativas acerca de nossos corpos. Narrativas essas que, dissidentes de qualquer tentativa binária, perceba os corpos como textos em/com provisoriedade constante. 
Textos aberrantes, em que métodos e técnicas não capturam nossas práticas políticas, no qual decididamente pensamos - refletindo aqui em torno de práticas de resistências acerca do dispositivo da moda - nas vestes apenas como tecidos que culturalmente nos protegem de nossa própria vergonha, e mais que isso, nosso convite é o de nos pensarmos desavergonhados, compreendendo tal vergonha como igualmente produzida. Não querendo com isso um novo Éden, mas ao invés disso, denotar como uma visualidade de gênero é compulsoriamente composta, constituída por signos que não se prendem somente ao sexo biológico - argumento esse que regulamenta e produz um estatuto natural ao sexo - e que necessita sempre de constante estimulação para consolidar seu mimetismo (BUTLER, 2015).

No seu caminhar, nosso corpo é, nessas tensões produtivas com o poder, objeto e instrumento de certa prática de resistência e oposição ao processo de iteração do normativo, "tendo em vista que reconhecer um gênero muitas vezes envolve reconhecer uma determinada conformidade corporal como uma norma, e as normas são até certo ponto compostas de ideais que nunca são completamente vivíveis" (BUTLER, 2018, p. 46). Funcionando o corpo, como um aparato de subjetivação no qual outras possibilidades constitutivas são produzidas, diluídas, reinventadas.

Tais corpos de saia visibilizam outras maneiras de pensar e estar no mundo. Estabelecendo tensões. E tensionar por uma política do aparecimento requer compreender que

[...] se um sujeito querer primeiro encontrar o próprio caminho dentro das normas que governam o reconhecimento, normas que nunca escolhemos e que encontraram o seu caminho até nós e nos envolveram com seu poder cultural estruturador e incentivador. E então, se não conseguimos encontrar nosso caminho dentro das normas de gênero ou sexualidade que nos foram designadas, ou só conseguimos encontrar nosso caminho com grande dificuldade, ficamos expostos ao que significa estar nos limites da condição de reconhecimento: essa situação pode ser, dependendo da circunstância, tanto terrível quanto emocionante (BUTLER, 2018, p. 47).

E nos limites do reconhecimento, os corpos podem produzir por meio da performatividade uma fenda na esfera do aparecimento, evidenciando por meio deste ato produtivo, como as contradições do normativo são antes de tudo, sua expressão mais recorrente, normas que funcionam ao mesmo tempo eficazes e falíveis.

E caminhando nas ruas, afetados e afetando em uma desatinada caminhada. Olhares, ruas, sentidos. Tal caminhar almeja desbravar outras possibilidades de conceber o corpo e como este, alcança outro. Desconcertando seu peito, seu gesto, sua boca, sua saia, enlace confuso de um corpo que se lança contingente.

Caminhar se torna, neste contexto, um importante direito político, haja vista que muitos outros corpos têm esse direito negado, tendo a violência incidindo sobre seus corpos - como as 
travestis, transexuais, transgêneres -, corpos sempre vitimados com a sentença de um fazer morrer por serem queers.

Em vários tempos históricos, o corpo tem sido território de disputas políticas efetivadas com o intuito de moldá-lo/esculpido pelos discursos; não precisaremos então, discorrer sobre como uma história do corpo foi constituída pelo poder, mas, sim, nos leques de seus dispositivos, discutir como se foi estabelecendo acerca do corpo uma vontade de verdade nos engendramentos dos discursos poder-corpo (SILVA, 2020b, p. 207).

Corpos sempre impossibilitados de viver uma vida vivível. Isso porque quando se torna possível caminhar nas ruas "desprotegido e ainda sim estar seguro, para que a vida diária se torne possível sem medo da violência, então certamente é porque existem muitos que apoiam esse direito mesmo quando ele é exercido por uma pessoa sozinha" (BUTLER, 2018, p. 58). E o direito de aparecer em uma sociedade farmacopornográfica, requer dos corpos que abraçam outras formas de vida generificada, rupturas e embates, pois, como nos aponta Butler,

aqueles que insistem que o gênero deve sempre aparecer de uma maneira ou com uma versão de vestuário em vez de outra, que buscam criminalizar ou patologizar aqueles que vivem seu gênero ou sexualidade de maneiras não normativas, estão agindo como a polícia da esfera do aparecimento, pertençam ou não a uma força policial de fato (BUTLER, 2018, p. 66).

É com essa polícia do aparecimento que a moda-militância busca travar embates, uma vez que, busca borrar certos efeitos de verdade sobre um campo específico de visualidade para os corpos, evidenciando como inúmeras são as possibilidades de trânsito que o gênero, em suas expressões, papéis e visualidade, abraça em sua ontologia contingente.

E não só isso, essa própria polícia do aparecimento denota em suas regulações acerca de quais corpos podem aparecer e quais não, como seus discursos em torno da visualidade normativa tida como natural são na verdade fabricados e fictícios, carecendo de várias instâncias reiterativas, que formulando seus status no presente, adquirem um efeito de natural e advogam interdição ao que não mimetiza seu efeito de verdade.

Produzir saberes desqualificados, não higienizados, imorais, desapaziguadores. Eis o nosso querer: manifestar a importância de pleitearmos outras formas de conhecimentos. Filosofias dissidentes que se apresentem como constantes problemas incitando o pensamento. Formas de habitar o presente, práticas que se constituem no cotidiano e que podem fomentar novas compreensões sobre nós mesmos e sobre o mundo.

Novos entendimentos sobre como travar no cotidiano, contra-produções que tensionam com o poder novas formas de conceber a arquitetura política dos corpos. Vendo que, neste 
terreno belicoso, cada gesto, cada ato, pode ser instrumento necessário de torção da norma em sua vontade constante de captura e enquadramento.

A convocatória é posta, um anúncio decisivo nestes dias em que nossos corpos se atrevem a entrever como reagir à reação reacionária. Esse gesto totalitário contra tudo o que tensiona a norma, tudo que advogue contra o discurso de um divino que regula, que problematize o argumento natural das instituições, com seus mecanismos de fabricação e regulamentação da vida.

Os corpos, neste sentido, são possíveis artefatos de uma nova engrenagem, de um lado produzindo contracondutas que cada vez mais possam almejar saturar os discursos naturalizantes - nem natureza, nem origem, nem verdade dada e imutável. Nada de universais. Somos compostos de contínuos movimentos -. Do outro sendo alvo de ferrenha perseguição sob vontade pérfida dos reacionários em suas limitadas argumentações da moralidade generificada, que, se sentindo ameaçados com os efeitos que nossos saberes difusos possibilitam, produzem no social um pânico moral, flertando com o totalitarismo querendo nossos corpos aniquilar.

Como saberes não se encerram na epiderme da pele, outros corpos de outrora, mesmo mortos ecoaram, somos um grito fantasmático, um eco de muitos, de tantos outros ceifados para consolidar um regime político, para a fabricação constante da heterossexualização do mundo, em que corpos dissidentes, são tanto a própria afirmação da norma, como seu exímio documento de limitação. É pelos que se foram e por nós que estamos. Convidamos a manifestar saberes dissidentes, a produzi-los, pirateá-los, xerocá-los, reinventá-los. Percebendo-os como continuamente em produção. Desarranjando assim todo um aparato que enseja capturar tudo que se apresenta em resistência ao normativo.

\section{III}

A insurreição é uma andança, um trilhar desatinado no raiar do dia. De saia ${ }^{i}$, - já desapropriada de qualquer clivagem de gênero, instrumento político desse devir - nossos corpos articulam outros movimentos. Será a composição de um abraço, uma volta, parte de uma dança alimentada pelo fogo do vento, fazendo do corpo um palco de enunciação em que a nossa teatralidade se abre para além de sua tão grandiosa capacidade. Courtine afirma, por exemplo, que, "o corpo humano era, e permanece para nós, coberto de signos, mesmo se a natureza destes, o olhar que os decifra, a posição de quem os interpreta e a intenção de quem os exprime se modificam historicamente" (COURTINE, 2013, p. 78). 
Figura 3 - Homem de saia.

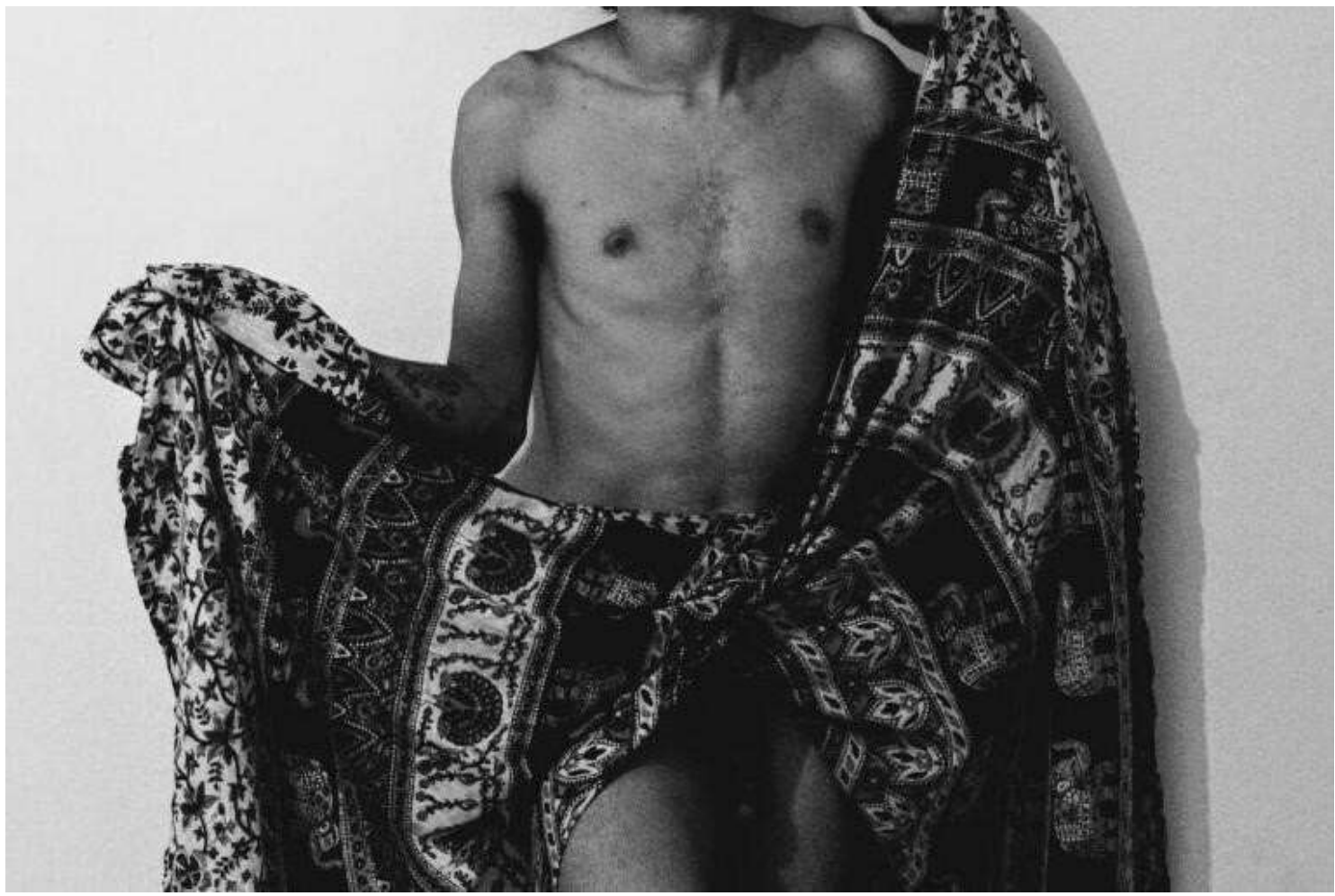

Foto: Thiago Antunes, 2017. 785 x 490, Recife-PE.

Nossos corpos desvelados se apropriam do direito de caminhar, se sempre nossos corpos quiseram governar, desapropriados pela força da dissidência, pela revolta, é por um aparecimento como política que continuaremos produzindo contracondutas nesta era farmacopornográfica (PRECIADO, 2018). Hackeando visibilidades únicas, imutáveis, padronizadas.

A nossa intenção não se apresenta como texto que produz uma continuidade da masculinidade como regime político nos corpos. A nossa força política reside na denúncia desses códigos - masculinidade e feminilidade -, compartilhando através da imagem pedagógica que nossos corpos podem constituir, registros abertos contrassexuais, buscando queerificar os aparatos que fabricam e nomeiam a visualidade de gênero na materialidade dos corpos. Pois como nos aponta Butler,

[...] algumas vezes não é uma questão de primeiro ter o poder e então ser capaz de agir; algumas vezes é uma questão de agir, e na ação, reivindicar o poder de que se necessita. Isso é a performatividade como eu a entendo e também uma maneira de agir a partir da precariedade e contra ela (BUTLER, 2018, p. 65).

Apagando essas composições, resta a evidente ruína do homem, já anunciada por Foucault (1999). Nessas tentativas de tecer possibilidades de manifestações, de anunciar o 
óbvio dos nossos dias, de apresentar em nossos corpos-textos a potência do nosso movimentar, gritaremos: não retrocederemos! Já somos os ciborgues (HARAWAY, 2009), já somos as quimeras que devoram os escombros da modernidade, que desmascaram os efeitos de verdade dos universais e da naturalizada arte de governamentalização da vida.

Seremos potentes tochas desse incêndio performativo que queima papéis, identidades e permanências. Unem-se ao nosso chamado, nessa luta contra o obscurantismo, outras tantas vozes. Conformaremos uma assembleia, uma revolta coletiva que pela ruptura que os encontros podem mobilizar, estabelecem possibilidades múltiplas que escapam as marcas de gênero. Advogando a abolição de todas as tentativas de enquadramentos, articulando outras formas de estar no presente que não se encerram na governamentalidade.

Nutridos de uma filosofia queer, desse modo superior de dar o cu, construiremos novas visualidades, pirateando a política da aparência, produzindo formas alternativas, errantes, aberrantes, que exploram, difundem e distribuem outras formas de tensão com o poder. Uma filosofia que longe de se propor sistêmica, lança-se como contínua indagação ao poder, percebendo a produção de conhecimentos como tecnologias políticas importantes que devemos utilizar nesse embate. Construiremos práticas de resistência, Butler percebe a resistência como esse conjunto que encontramos

\begin{abstract}
no ato do discurso verbal ou na luta heróica, mas também nos gestos corporais de recusa, silêncio, movimento e recusa em se mover que caracterizam os movimentos que representam os princípios democráticos da igualdade e os princípios econômicos da interdependência na própria ação por meio da qual reivindicam um novo modo de vida mais radicalmente democrático e mais substancialmente interdependente (BUTLER, 2018, p. 238).
\end{abstract}

Radicalizando nossas práticas corporais, tomando de assalto técnicas, bugando um único estatuto do saber, concebendo o queer como um conjunto de saberes que produzem outras formas de inteligibilidade, outras ressignificações em torno de nossas compreensões sobre o mundo e intentando contra todo efeito policial do poder; rearticularemos táticas de guerra, denunciando esta contínua espionagem farmacopornográfica, esse fazer viver que tenta se apropriar cotidianamente de nossos corpos visando sua disciplinarização e regulamentação. As tensões produtivas do corpo podem se apresentar como reverberações, não um saber neutro sobre o corpo, ou dito de outra maneira, o corpo não é um dado passível onde age o poder, o que

quer dizer que pode haver um 'saber' do corpo que não é exatamente a ciência de seu funcionamento, e um controle de suas forças que é mais que a capacidade de as vencer: esse saber e esse controle constituem o que se poderia chamar de tecnologia política do corpo (FOUCAULT, 2014, p. 30). 
Cada ato de nosso caminhar deverá ser pensado como parte de uma performance, sua escritura política objetiva ecoar narrativas, visibilizar um movimento polimorfo, um toque, um desassossegado entoar, um balanço ligeiro, que aparece para não desaparecer, que caminha pelo direito de caminhar, que luta por já se enlutar demasiadamente.

Dançaremos nas ruas. Passos rítmicos, ordenadamente descompassados, poeticamente comprometidos. A arte desse movimento é como sempre foi toda arte na história do ocidente: renegada. É a herança dionisíaca dos renegados, da arte que o corpo tece nos enlaces que constitui. Cientes de nosso objetivo, caminharemos empenhados no gesto que sucede o chamado de nossa atuação.

Sendo vistos, proclamaremos nossa blasfêmia, nossa anti-pregação, a qual reivindica em sua eloquência a profanação das maculadas instituições que gerem a vida. Pleiteamos, mesmo sem exterioridade, a norma, nossas resistências, nossos contratos contrassexuais que tensionam outras possibilidades de uma experiência de si.

\section{IV}

Nossa crítica e reivindicação se localiza nos limites que os efeitos de verdade apresentam, quando através de nossas imagens pedagógicas queerificamos e tensionamos as normas de reconhecimento. Os efeitos dessa imagem pedagógica são extremamente produtivos, pois articulam e colocam em questão compreensões naturalizadas do social acerca de nossa própria visualidade.

Queremos com isso mostrar como são possíveis formas diferentes de habitar o presente, que podemos piratear e xerocar na materialidade de nossos corpos, formas de vida que escapem de padronizações. Claro que, o poder não deixará de fabricar formas sofisticadas de governo. Mas é através da busca de formas de governo de si, de tomarmos de assalto as rédeas de nossa subjetividade, de inventamos um outro de nós mesmos que empreendemos nossa busca política.

Buscamos parodiar formas exaustivas de feminilidade e masculinidade, defendendo em contrapartida uma (in)certeza queer, ou seja, a contingência, a dissidência, a contrassexualidade. Evidenciando que o gênero como programa operacional que fabrica em nossa superfície tecno-orgânica sua materialização pode ser hackeado. Uma de nossas táticas é parodiarmos seu mito de originalidade. Nossos corpos

sempre algo mais do que apenas corpos, tecem, mesmo na precariedade, possibilidades performativas, ecoam textos que reivindicam outras formas de viver que não estejam instadas a um estatuto do reconhecimento. Resultados não previstos, 
formas de vida que desafiam os esquemas e as táticas normativas (SILVA, 2020a, p. 09).

As vestes/roupas, neste sentido, serão utilizadas por nós de formas diferentes ao que fabrica o dispositivo da moda, se este naturaliza seu regime do vestir 'calça para homem, saia para mulher' levantamos nossos corpos como uma bandeira independente, como uma força que media outras relações com o vestir, vendo-as a partir disso, desemparelhadas de qualquer atributo de gênero (SILVA, 2020b).

Saias, calças, ternos, entre outras peças, artefatos do dispositivo da moda, serão utilizados como vestes por qualquer corpo falante, nosso contrato será o de sempre propor poluir qualquer visualidade específica para o vestir. Encaramos as vestes/roupas como se deveriam vê-las: apenas como vestes/roupas. Nosso efeito moda-militância poderá incitar inquietações necessárias nestes tempos de morbidez. Aparecer confundindo as normas de escritura de sexo e de gênero é um dos nossos atos performativos, performances necessárias, que politizam o vestir, bem como anunciam a aurora da ruína de sua padronização.

A moda-militância pode ser pensada após se nutrir desse caminho teórico-político, como uma performance dissidente que denuncia o dispositivo da moda, bem como apresenta o caráter imitativo da própria visualidade de gênero, sempre necessitando de signos específicos para constituir uma masculinidade e uma feminilidade que são sempre apresentadas como imutáveis e naturais.

No agoniado cotidiano que nos observa, em uma era farmacopornográfica (PRECIADO, 2018) em que funciona uma 'arte de governar' que estabelece um estatuto do aparecimento - no qual, de um lado marca no campo da legitimidade social quais corpos visibilizam o normativo sendo, portanto, vivíveis; e do outro, circunscreve a precariedade ${ }^{\mathrm{ii}}$ na realidade de corpos que não mimetizam o normativo, instando-os a vidas precárias -; o ato de caminhar, de mover-se, pode ser compreendido, neste sentido, como um enfrentamento político pelo direito de aparecer e estar nas ruas.

Outra reivindicação mais ampla que buscamos construir nestas notas de nossa manifestação é abdicarmos da identidade como princípio de nossa constituição. Articulamos uma proposta pós-identitária e pós-humana querendo com isso projetar outras possibilidades de concebermos nossa provisoriedade. Nossa defesa é de nos perceber provisórios, sempre em constante mutação.

Decretando o fim dos signos das identidades que mobilizam a emergência do gênero como aparato que conforma a integridade do sujeito, em que a regulação pública produz uma 
norma de reconhecimento que renega toda visualidade que perturbe seu efeito naturalizado. Disputamos habitar o presente, manifestar nossa paródia, confundir as certezas.

Desgovernando com nossa contrassexualidade, os efeitos do sistema de sexo e de gênero, os efeitos que a heterossexualidade compulsória produz em sua reiteração normativa poderão com isso serem fortemente abalados. Fabricando cibertecnologias para nossos corpos, o binarismo desfalece, corroborando na emergência de um Agender, de formas de vida que se lançam para além da apropriação dos corpos apenas como masculinos e femininos. Percebendo que nossos corpos

não passam de máquinas, produtos, instrumentos, aparelhos, truques, próteses, redes, aplicações, programas, conexões, fluxos de energia e de informação. Interrupções e interruptores, chaves, equipamentos, formatos, acidentes, detritos, mecanismos, usos, desvios... (PRECIADO, 2014, p. 23).

Nestas notas, manifestamos igualmente nosso desassossegado movimento, escapando as marcas e a estabilidade de um sistema heterocentrado, assim como os privilégios que a heterossexualização do mundo produz. Valorizamos então, práticas que desestabilizam esse regime político, que apresentem as nefastas consequências de sua institucionalização.

No gesto que se anuncia, almejamos resistir à guerra que se sucede no cotidiano, conflito esse em que percebemos alguns corpos, dentre eles os corpos queer, como alvo dessa ameaça. Cansados então de sermos mortos, torturados e silenciados, juntos intentamos aparecer, mostrando que somos muitos e que produções performativas são mobilizadas pela força política de nosso encontro, de nosso trilhar, da reverberação da imagem pedagógica que constituímos. Longe de temer, queremos percorrer as ruas, tomando-a das mãos da polícia do aparecimento, pensando formas de manifestações que não caiam no vespeiro do imobilismo, na permanência que limita nossas possibilidades, que congela o quente movimentar que podemos engendrar, que interdita a ação política que nossos corpos juntos podem visibilizar e dizibilizar.

\section{V}

Esses rascunhos aqui talhados ensejam provocar, que os deslocados por suas poéticas possam se sentir atraídos como Narciso em sua beleza, que afetados possam abraçar esse devircorpo, corpo-texto. Que busquem constituir na arquitetura de sua superfície uma imagem pedagógica. Saberes outros que não direcionam aos corpos um significado único.

Que um a um, nas ruas, possamos vislumbrar a nossa ação, degustar a afetação dos outros, ouvir os gritos impetuosos dos moralistas que regulam e sentir os efeitos que tal motivação noticia. Estimulados vamos extrapolar os limites que imputaram para nós, 
desassossegados, seguiremos com atenção nesta escritura desprovida de origem que iremos compor.

Convocamos esta insurgência, todos a postos, o movimento é contínuo. Uma assembleia de corpos que conformam alianças e tecem um texto performativo que produz, grita, ecoa. Esta ocupação por uma vida vivível se denota cada vez mais possível, quando reparamos o pânico daqueles que querem ser nossos algozes, que desejam governar nossos corpos.

Corpos falantes, falanges degredadas, armas de um devir-revolução. O início do fim da distopia do regime político dos corpos. Nosso campo de batalha são as ruas, disputando pelo direito de aparecer, estabelecendo embates com o poder. Nossa guerra é estética, cibernética, semiótica, midiática, somatopolítica. Nossos inimigos: discursos de normalização.

Expulsando de nós qualquer vontade de verdade, desejamos apenas construir produções em torno do que estamos sendo, dos nossos doentes dias e da fatídica realidade que nos circunda. Tecer um texto inquieto que possa incitar problemas, facultar a confusão e o conflito entre concepções naturalizadas e, a denúncia de sua fabricação e ficção. Corpos em movimento, reverberações discursivas de corpos-textos, imagens pedagógicas, deslocando, inquietando, mobilizando, anarquizando, desnaturalizando, talhando novas possibilidades de subjetivação. Tensionando com o poder outras formas de resistência que já não estejam capturadas em sua contínua sofisticação.

Agindo politicamente em nossos corpos, essas notas poderão se tornar performativas, escritas provisórias para tecer manifestações. Em movimento, sacudimos e provocamos o processo de fabricação da normatividade, e gritamos aos que querem gerir nossa vida: isso não é um manifesto! É a anárquica performance dele!

\section{Referências}

BUTLER, J. Problemas de Gênero: feminismo e subversão da identidade. Tradução de Renato Aguiar. $8^{\circ}$ ed. Rio de Janeiro: civilização Brasileira, 2015.

BUTLER, J. Corpos em aliança e a política das ruas: notas para uma teoria performativa de assembleia. Tradução de Fernanda Siqueira Miguens. $1^{\mathrm{a}}$ ed. - Rio de Janeiro: civilização Brasileira, 2018.

COURTINE, J. Decifrar o corpo: pensar com Foucault. Tradução de Francisco Morás. Petrópolis-RJ: Vozes, 2013.

FOUCAULT, M. As palavras e as coisas: uma arqueologia das ciências humanas. Tradução de Salma Tannus Muchail. 8a . ed. São Paulo: Martins Fontes, 1999. 
FOUCAULT, M. Vigiar e punir: nascimento da prisão. Tradução de Raquel Ramalhete. 42a . ed. Petrópolis, RJ: Vozes, 2014.

HARAWAY, D. Manifesto Cyborg: Ciência, Tecnologia e Feminismo Socialista no Final do Século XX. In: SILVA, T. T. (org.). Antropologia do Ciborgue. Belo Horizonte: Autêntica Editora, 2009.

LOURO, G. L. Gênero, sexualidade e educação: uma perspectiva pós-estruturalista. Petrópolis, RJ: Vozes, 1997.

PRECIADO, P. B. Manifesto contrassexual: práticas subversivas de identidade sexual. Tradução de Maria Paula Gurgel Ribeiro. São Paulo: n-1 edições, 2014.

PRECIADO, P. B. Testo Junkie: sexo, drogas e biopolítica na era farmacopornográfica. São Paulo: N-1 edições, 2018.

SILVA, R. G. Biopolítica, precariedade e educação: um ensaio de pensamento com Butler e Foucault. Linhas Críticas, v. 26, p. 1-17, ago., 2020a.

SILVA, R. G. Corpo, masculinidade, moda e biopolítica: apontamentos para uma genealogia da saia. Revista Periódicus, v. 1, n.13, mai.-ago., 2020 b.

\footnotetext{
' Este estudo é parte da Dissertação de Mestrado em Educação intitulada "Isso não é um manifesto: corpo, performance, moda-militância e imagem pedagógica", defendida pelo autor em 2019, na Universidade Federal de Pernambuco.

ii Vale assinalar que, por precariedade, concebemos "a condição politicamente induzida de vulnerabilidade e exposição maximizadas de populações expostas à violência arbitrária do Estado, à violência urbana ou doméstica, ou a outras formas de violência não representadas pelo Estado, mas contra quais os instrumentos judiciais do Estado não proporcionam proteção suficientes" (BUTLER, 2018, p. 41).
} 